\title{
The potential of a New Zealand strain of Phasmarhabditis hermaphrodita for biological control of slugs
}

\author{
M.J. Wilson ${ }^{1}$, G. Burch ${ }^{1}$, M. Tourna ${ }^{1}$, L.T. Aalders ${ }^{1}$ and G.M. Barker ${ }^{2}$ \\ ${ }^{1}$ AgResearch, Ruakura Research Centre, Hamilton, New Zealand \\ ${ }^{2}$ Landcare Research, Hamilton, New Zealand \\ Corresponding author: Michael.Wilson@agresearch.co.nz
}

\begin{abstract}
In New Zealand, the European invasive slug Deroceras reticulatum is a pest in home gardens, horticulture, pastoral and arable agriculture. At present there are no biological control options available in New Zealand, unlike Europe, where the nematode parasite Phasmarhabditis hermaphrodita is sold in several countries under the trade name Nemaslug ${ }^{\circledR}$. This paper describes the finding of a nematode parasitising D. reticulatum in New Zealand that was identified by morphological and molecular (18S rDNA sequencing) methods as $P$. hermaphrodita. The nematode was reared on slug cadavers and shown to infect and kill field-collected D. reticulatum. In mesocosm experiments with clover, the New Zealand $P$. hermaphrodita applied at the recommended commercial rate substantially increased plant density even under high slug pressure.
\end{abstract}

Keywords slugs, nematodes, biological control, clover.

\section{INTRODUCTION}

Terrestrial molluscs are pests of a broad range of crops throughout the world (Barker 2002). In New Zealand they have been well studied as pests of pasture establishment, particularly damaging clover (Wilson \& Barker 2011). Current control relies on use of bait pellets containing either metaldehyde, methiocarb or chelated iron phosphate compounds (Rae et al. 2005).

In Europe the nematode parasite Phasmarhabditis hermaphrodita is sold as a biological molluscicide under the trade name Nemaslug ${ }^{\circledR}$ by the US company Becker Underwood (Rae et al. 2007). This nematode is a facultative parasite of slugs that forms infective dauer larvae. These larvae seek out slugs and penetrate the mantle cavity through a natural opening. Once inside, the larvae develop into adults and reproduce, killing the host typically within 7-21 days and then nematodes feed on the cadaver (Wilson et al. 1993; Tan \& Grewal 2001a). While time until death is quite long, slugs cease feeding within days of infection (Glen et al. 2000). The nematode can infect several species of slugs and snails (Wilson et al. 1993; Wilson et al. 2000), but is particularly effective at controlling Deroceras reticulatum (the grey field slug). The nematode is mass produced in association with the bacterium Moraxella osloensis and there is some evidence that presence of $M$. osloensis enhances virulence (Wilson et al. 1995; Tan \& Grewal 2001b). However, Rae et al. (2010) found no evidence that $M$. osloensis naturally associates with 
P. hermaphrodita analogous to the commercially available entomopathogenic nematodes (nematodes of the families Heterorhabditidae and Steinernematidae that associate with Photorhabdus spp. and Xenorhabdus spp. bacteria respectively). The production and formulation technology developed for entomopathogenic nematodes is readily adaptable for production of $P$. hermpahrodita allowing very high production levels to be achieved.

During dissection of a specimen of the New Zealand native slug Athoracophorus bitentaculatus collected from Opepe Historic Reserve near Taupo, New Zealand, an unidentified nematode dauer larva was found. Destructive DNA sequencing identified this as $P$. hermaphrodita. In order to establish a culture of this nematode, numerous individuals of the invasive European slug species $D$. reticulatum (the preferred host of $P$. hermaphrodita) were collected from the same site. These were allowed to die naturally and cadavers were examined for the presence of nematodes. If nematodes were present, individual gravid females were transferred to heat killed slug cadavers to establish cultures, according to the methods of Wilson (2012). The current paper describes work done using one such culture to identify the nematodes and test their virulence against $D$. reticulatum.

\section{MATERIALS AND METHODS}

Deroceras reticulatum for experimental use were field-collected at Ruakura Research Centre, Hamilton, New Zealand. Nematodes were reared on cadavers of field-collected $D$. reticulatum slugs that had been killed by immersion in boiling water to kill any nematodes naturally infesting them. The cadavers were placed in modified white traps (Wilson 2012) at $15^{\circ} \mathrm{C}$ and emerging dauer juveniles were collected in tap water and stored at $4^{\circ} \mathrm{C}$ until used.

\section{$18 \mathrm{~S}$ rDNA sequencing}

Individual dauer juveniles were handpicked, ruptured and DNA extracted using the Zygem PrepGEM Tissue DNA extraction kit (ZyGEM Corporation Ltd., Hamilton, New Zealand).
Extracted template DNA $(2 \mu \mathrm{l})$ was added to $23 \mu \mathrm{l}$ reaction mixture consisting of $1 \mathrm{U}$ Taq polymerase (Velocity Taq, Bioline), $1 \times$ reaction buffer (containing $2 \mathrm{mM} \mathrm{MgCl}_{2}$ ), $1 \mathrm{mM}$ dNTPs, $0.4 \mu \mathrm{M}$ forward primer SSU F07 (Blaxter et al. 1998), $0.4 \mu \mathrm{M}$ reverse primer $18 \mathrm{P}$ (Blaxter et al. 1998) and $0.2 \mathrm{mg} / \mathrm{ml}$ bovine serum albumin (BSA). PCR used an initial denaturation step at $98^{\circ} \mathrm{C}$ for $2 \mathrm{~min}$ followed by 35 cycles of denaturation at $98^{\circ} \mathrm{C}$ for $30 \mathrm{sec}$; annealing at $55^{\circ} \mathrm{C}$ for $30 \mathrm{sec}$; extension at $72^{\circ} \mathrm{C}$ for $45 \mathrm{sec}$, followed by a final extension step at $72^{\circ} \mathrm{C}$ for $5 \mathrm{~min}$. PCR product (1681 bp) was cleaned using the ENZA purification Kit (OMEGA bio-tek, New Zealand) and quantified spectrophotometrically prior to sequencing at the Massey genome service facilities (Massey University, New Zealand). Sequence data were refined then assembled using the Sequencer 4.1 program (Genes Codes Corp., Ann Arbor, Michigan, USA).

\section{Petri dish bioassay}

An initial assay aimed to test the ability of a high dose of the New Zealand P. hermaphrodita to inhibit feeding by, and kill, D. reticulatum. Slugs were exposed to nematodes in $11 \mathrm{~cm}$ diameter glass Petri dishes containing $60 \mathrm{~g}$ potting mix. Nematodes (9500 per dish, $=100 / \mathrm{cm}^{2}$ ) were applied in $10 \mathrm{ml}$ tap water and untreated plates received $10 \mathrm{ml}$ tap water. Each dish contained 10 D. reticulatum and three replicate dishes were prepared per treatment. Plates were incubated at $15^{\circ} \mathrm{C}$. After 5 days, individual surviving slugs were transferred to plastic $9 \mathrm{~cm}$ Petri dishes lined with moist filter paper. In order to assess feeding, each dish received a pre-weighed $2 \mathrm{~cm}$ disc of cabbage leaf, which was removed and reweighed after 3 days. Slugs were kept in the Petri dishes for a further 5 days and mortality recorded. Weight of cabbage consumed by treated and untreated slugs was compared using a $t$ test. Mortality at the end of the experiment was compared with the $x^{2}$ test.

\section{Clover establishment experiment}

The experiment used plastic troughs $(32 \times 14$ $\times 12 \mathrm{~cm}$ deep) filled with $2 \mathrm{~kg}$ moist potting compost to a depth of approximately $7 \mathrm{~cm}$. Fifty 
white clover seeds (cv. Sustain) were planted in two rows of 25 in each trough. Nematodes were added to four troughs at the recommended field rate $\left(13,440\right.$ per trough $\left.=30 / \mathrm{cm}^{2}\right)$ in $100 \mathrm{ml}$ tap water. Four control troughs were prepared with $100 \mathrm{ml}$ tap water. Two adult $D$. reticulatum were added to each of these troughs $\left(=44 / \mathrm{m}^{2}\right)$, which were then sealed with cling-film secured with a rubber band. A further two troughs of 50 seeds were prepared as above but without added slugs to estimate germination rate. Troughs were incubated at $15^{\circ} \mathrm{C}$ for 7 days after which numbers of established seedlings were counted. The experiment was repeated. Plant establishment data were analysed using ANOVA followed by an LSD test.

\section{RESULTS}

Adult hermaphrodite nematodes within the cultures were identified as P. hermaphrodita and this was confirmed by the $18 \mathrm{~S}$ rDNA sequence that shared $99 \%$ similarity with the sequence of the UK isolate of $P$. hermaphrodita. The sequence has been deposited in GenBank (accession number JQ965811).

In the Petri dish experiment, feeding measured between 5 and 8 days after exposure was significantly $(\mathrm{P}<0.001)$ inhibited by presence of nematodes (Figure 1a), and at the end of the experiment (13 days), there was a highly significant $(\mathrm{P}<0.001)$ association between presence of nematodes and slug mortality (Figure 1b).

The two separate clover establishment experiments showed similar trends so data were pooled for analysis (Figure 2). ANOVA revealed highly significant differences in clover establishment between treatments $(\mathrm{P}<0.001)$. The slug density in the current experiment was sufficiently high that clover in the untreated controls was almost completely consumed by slugs. However, even when faced with this high slug pressure, the $P$. hermaphrodita-treated troughs had a significantly improved plant density $(\mathrm{P}<0.001)$ although this was significantly less than in troughs without added slugs $(\mathrm{P}<0.001)$.
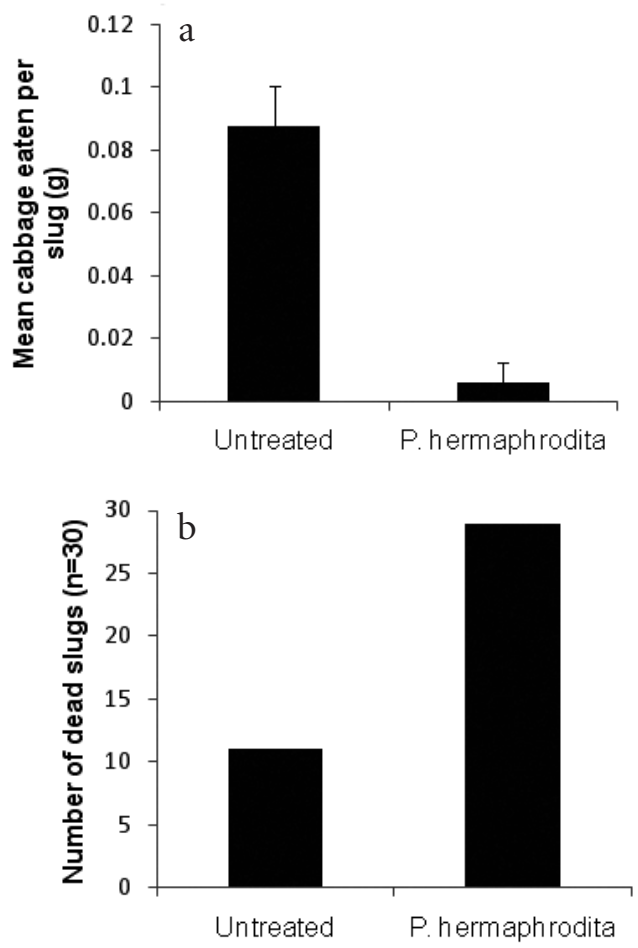

Figure 1 Petri dish bioassay of Phasmarhabditis hermaphrodita against Deroceras reticulatum. (a) Mean consumption (+ SE) of cabbage by surviving slugs between 5 and 8 days after initial exposure to P. hermaphrodita. (b) Slug mortality at the end of the experiment, 13 days after initial exposure to $P$. hermaphrodita.

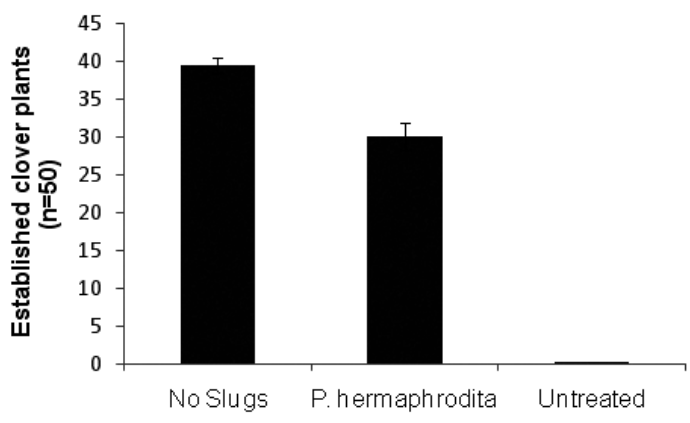

Figure 2 Mean numbers of established clover plants after 1 week in troughs containing D. reticulatum slugs with or without P. hermaphrodita. Control troughs without slugs were also included to estimate seed germination rate. 


\section{DISCUSSION}

This is the first report of $P$. hermaphrodita being present in New Zealand. This nematode was probably introduced from Europe as a soil contaminant or in association with one or several slug and snail species that have accidently been brought to this country. Previously the nematode has been found in France, Germany, the UK, Iran and Chile (Rae et al. 2007). Furthermore, the finding of $P$. hermaphrodita dauer larvae in the New Zealand native slug Athoracophorus bitentaculatus represents a new host record. Because only a single dauer larva was found in this slug, it is not possible to say whether $P$. hermaphrodita is actually a parasite of this species, or whether it uses this slug as a necromenic host (in which nematode larvae enter the slug, but do not develop and reproduce until the slug dies, after which the nematodes feed on the cadaver). Phasmarhabditis hermaphrodita is known to associate necromenically with several species of slugs and indeed, prior to the work of Wilson et al. (1993), P. hermaphrodita was not believed to be a parasite (Mengert 1953).

The New Zealand P. hermaphrodita is clearly highly infective to the pest slug $D$. reticulatum, inducing strong feeding inhibition and mortality. In the clover establishment experiment that used a highly damaging slug density, presence of nematodes significantly increased plant establishment, although plant numbers were less in nematode-treated troughs than in troughs without added slugs. However, in a field situation it would be possible to treat the soil with nematodes several days prior to drilling, thus allowing the nematodes time to infect slugs and inhibit their feeding before vulnerable seedlings emerged. Furthermore, in these clover establishment experiments, slugs could rest on the side of the troughs, thus avoiding contact with nematodes in the soil. Since slugs are known to avoid contact with nematodes if possible (Wilson et al. 1999), this factor is likely to have reduced nematode efficacy in the present experiment.

It is believed that this nematode has potential for development as a biological mollucicide in New Zealand. In addition to pasture, introduced slugs damage a wide range of horticultural crops and home gardens in New Zealand, and it is likely that if $P$. hermaphrodita was marketed in New Zealand as a commercial molluscicide, these higher value markets would be targeted initially.

\section{ACKNOWLEDGEMENTS}

This work was funded by an AgResearch AR\&C grant and through the MSI Microbial Products Programme C10X0706.

\section{REFERENCES}

Barker GM 2002. Molluscs as crop pests. CABI Publishing, Wallingford, UK. 400 p.

Blaxter ML, de Ley P, Garey JR, Liu LX, Scheldeman P, Vierstraete A, Vanfleteren JR, Mackey LY, Dorris M, Frisse LM, Vida JT, Thomas WK 1998. A molecular evolutionary framework for the phylum Nematoda. Nature 392: 71-75.

Glen DM, Wilson MJ, Brain PB, Stroud G 2000. Feeding activity and survival of slugs, Deroceras reticulatum, exposed to the rhabditid nematode, Phasmarhabditis hermaphrodita: a model of dose response. Biological Control 17: 73-81.

Mengert H 1953. Nematoden und schneken. Zeitschrift fur Morphologie und Okologie Tiere 41: 311-349.

Rae RG, Robertson JF, Wilson MJ 2005. Modern developments in slug control. Outlooks on Pest Management 16: 27-30.

Rae RG, Verdun C, Grewal PS, Robertson JF, Wilson MJ 2007. Biological control of terrestrial molluscs using Phasmarhabditis hermaphrodita - progress and prospects. Pest Management Science 63: 1153-1164.

Rae RG, Tourna M, Wilson MJ 2010. The slug parasitic nematode Phasmarhabditis hermaphrodita associates with complex and variable bacterial assemblages that do not affect its virulence. Journal of Invertebrate Pathology 104: 222-226.

Tan L, Grewal PS 2001a. Infection behaviour of the rhabditid nematode Phasmarhabditis hermaphrodita to the grey garden slug Deroceras reticualtum. Journal of Parasitology 87: 1349-1354. 
Tan L, Grewal PS 2001b. Pathogenicity of Moraxella osloensis, a bacterium associated with the nematode Phasmarhabditis hermaphrodita, to the slug Deroceras reticulatum. Applied and Environmental Microbiology 67: 5010-5016.

Wilson MJ 2012. Pathogens and parasites of terrestrial molluscs. In: Lacey LA ed. Manual of techniques in invertebrate pathology, second edition. Academic Press, San Diego, USA. Pp 429-441.

Wilson MJ, Barker GM 2011. Slugs as pasture pests. Proceedings of the New Zealand Grassland Association 72: 241-246.

Wilson MJ, Glen DM, George SK 1993. The rhabditid nematode Phasmarhabditis hermaphrodita as a potential biological control agent for slugs. Biocontrol Science and Technology 3: 503-511.
Wilson MJ, Glen DM, George SK, Pearce JD 1995. Selection of a bacterium for the mass production of Phasmarhabditis hermaphrodita (Nematoda Rhabditidae) as a biocontrol agent for slugs. Fundamental and Applied Nematology 18: 419-425.

Wilson MJ, Hughes LA, Jefferies D, Glen DM 1999. Slugs, (Deroceras reticulatum and Arion ater agg.) avoid soil treated with the rhabditid nematode Phasmarhabditis hermaphrodita. Biological Control 16: 170-176.

Wilson MJ, Hughes LA, Hamacher GM, Glen DM 2000. Effects of Phasmarhabditis hermaphrodita on non-target molluscs. Pest Management Science 56: 711-716. 